metabolism was studied in vitro. Rapid ingestion of food was accompanied by an increase in the incorporation of isotope-labelled pyruvate into glyceride-glycerol and fatty acids, as well as by increased activity of glycerol-3-phosphate dehydrogenase. These results suggest enhanced lipogenesis during a gorging regimen. Though the evidence is by no means conclusive, this study provides a further indication that taking infrequent meals may be associated with a tendency to obesity and hyperlipidaemia. The modern Western tendency is to eat a large proportion of the day's calories at one evening meal. Though infrequent feeding is probably not pathogenic in itself, it may become so when combined with a high-calorie intake and a low-energy expenditure. Whether or not the high incidence of atherosclerosis which afflicts man, and which has been correlated with serum lipid levels, can be influenced by alteration of the pattern of food intake is at present unknown, but this question deserves further study.

1 Cohn, C., Federation Proceedings, 1964, 23, 76.

2 Cohn, C., and Joseph, D., Metabolism, 1960, 9, 492.

3 Jagannathan, S. N., Connell, W. F., and Beveridge, J. M. R., American fournal of Clinical Nutrition, 1964, 15, 90 .

Bortz, W. M., Wroldsen, A., Issekutz, B., and Rodahl, K., New England fournal of Medicine, 1966, 274, 376.

Swindells, Y. E., Holmes, S. A., and Robinson, M. F., British Fournal of Nutrition, 1968, 22, 667.

Finkelstein, B., and Fryer, B. A., American fournal of Clinical Nutrition, 1971, 24, 465 .

Gwinup, G., Byron, R. C., Roush, W. H., Kruger, F. A., and Hamwi, G. J., American Fournal of Clinical Nutrition, 1963, 13, 209.

Fábry, P., Hejda, S., Cerny, K., Osancová, K., and Pechar, J. American fournal of Clinical Nutrition, 1966, 18, 358.

Fabry, P., Fodor, J., Hejl, Z., Braun, T., and Zvolánková, K., Lancet, 1964, 2, 614.

10 Fabry, P., Fodor, J., Hejl, Z., Geizerova, H., and Balcarova, O., Lancet, 1968, 2, 190

11 Bray, G. A., Fournal of Clinical Investigation, 1972, 51, 537.

\section{Toxicity of Thallium}

Thallium is an extremely toxic and cumulative poison. Within three years of its discovery in 1861 a paper was published 1 warning of its toxicity to animals and man. The degree of toxicity has been variously estimated as lying somewhere between that of lead and arsenic. But the recent trial of Graham Frederick Young 2 for poisoning two of his workmates is said to be the first case of homicide by thallium in British legal history.

Like most elements soon after their discovery, the thallium salts have been tried for the treatment of certain chronic inflammatory diseases. They were also used as a temporary depilatory in cases of ringworm of the scalp. But their frequently poisonous effects led to thallium therapy being abandoned. The difficulty is that the therapeutic dose is too close to the lethal dose. E. Browning ${ }^{3}$ gives the therapeutic dosage as being $8 \mathrm{mg}$ of thallium acetate per $\mathrm{kg}$ bodyweight, while $12 \mathrm{mg}$ per $\mathrm{kg}$ is the minimum lethal dose for an adult.

But in industry the use of thallium is increasing. Because of its high refractive index it is incorporated into the manufacture of optical lenses, in infra-red optical instruments, and in imitation precious jewellery. It is used in alloys along with silver and lead, serves as a catalyst in a number of organic reactions, and has also been included in fireworks. Recently thallium salts have been used in the crystals which serve as scintillation counters. But it is in the form of rodenticides and insecticides that thallium constitutes the main hazard to the general public.

Thallium salts can enter the body in three ways-by inhalation as a dust, by ingestion either from contaminated food or from the hands, or by absorption through the skin. J. C. Munch ${ }^{4}$ examined the reports of 12 non-fatal cases of industrial poisoning and established that the main symptoms were fatigue, limb pains, and loss of hair. More severe poisoning results in peripheral neuritis, proteinuria, and joint pains, but occasionally neurological signs are the presenting factors. A striking example of non-industrial poisoning was described by Munch and colleagues 5 in 1933 from California. At least 30 people accidentally ate barley grain impregnated with $1 \%$ thallium sulphate intended as a rodenticide. Six died of acute thallitoxicosis within 16 days and a seventh two months later; and 20 persons developed gastroenteritis, abdominal colic, peripheral neuritis, strabismus, disorientation, convulsions, joint pains, and alopecia, mostly within three days. A similar accident involving nine members of three families occurred, despite warnings, in Mexico in 1964.

Recently W. J. Bank and colleagues ${ }^{6}$ studied five patients with thallium intoxication, two of whom were children who had eaten poisoned bait. All of them developed neurological symptoms, and alopecia was present in four of the five. They stress the importance of including thallium in the differential diagnosis when early bizarre neurological signs present themselves. Furthermore they advocate the use of a simple screening test of urine for thallium salts.

The treatment of thallium poisoning poses some difficulties. The principle is to increase urinary and faecal excretion, though the rate of each is slow. Chelating agents have been proposed, but results with these have been inconstant. 7 In addition potassium chloride is useful, but Bank and colleagues ${ }^{6}$ point out that such a regimen is limited by the amount of thallium that can be released into the blood without worsening the symptoms. However, it is probably the better method of treatment of the two.

While thallium salts continue to be used as rodenticides the danger of accidental poisoning, especially to children, will continue to exist. So long as the hazard remains, its possibility should be borne in mind in all cases of unexplained neurological symptoms and peripheral joint pains. The early use of a screening test on the urine would appear to be far better than waiting to see if the hair falls out.

\footnotetext{
1 Grandeau, L., fournal Anatomie Physiologie Normales Pathologiques Homme et Animaux, 1864, 1, 378

2 British Medical fournal, 1972, 3, 70.

3 Browning, E., Toxicity of Industrial Metals, 2nd edn. London, Butterworth, 1969.

Munch, J. C., Fournal of the American Medical Association, 1934, 102, 1929. Munch, J. C., Ginsburgh, H. M., and Nixon, C. E., Fournal of the American Medical Association, 1933, 100, 1315

- Bank, W. J., Pleasure, D. E., Suzuki, K., Nigro, M., and Katz, R., Archives of Neurology, 1972, 26, 456.

7 Sunderman, F. W., Paynter, O. E., and George, R. B., American fournal of the Medical Sciences, 1967, 254, 24.
}

\section{Urinary Incontinence in Women}

The diagnosis of stress incontinence is often difficult. It requires differentiation from frequency, urgency. and urge incontinence, and even very rarely from true incontinence due to a small urinary fistula.

The abnormality underlying the symptom is not always clear, for even the famed loss of the posterior urethrovesical angle, seen by cine-radiography, is not present in 